\title{
Pemodelan Hubungan Hujan dan Aliran Permukaan pada Suatu DAS dengan Metoda Beda Hingga
}

\author{
Dantje Kardana Natakusumah, M. Syahril B. Kusuma, Hendra Darmawan, \\ M. Bagus Adityawan \& M. Farid
}

Kelompok Keahlian Teknik Sumber Daya Air, Institut Teknologi Bandung

\begin{abstract}
Hujan menimbulkan aliran di daratan, baik aliran permukaan maupun aliran di dalam tanah. Pada jurnal ini, akan dibahas mengenai perangkat lunak yang dapat digunakan untuk memodelkan aliran di permukaan. Perangkat lunak ini dikembangkan berdasarkan persamaan Saint Venant, dengan menggunakan skema pengepingan MacCormack 2D. Perhitungan limpasan permukaan terhadap waktu dilakukan untuk 5 profil permukaan tanah yang berbeda, profil datar, segitiga, parabolik, dan 2 profil alam. Pada profil yang berbentuk datar, dilakukan perbandingan solusi antara analitik dan numerik yang menunjukkan bahwa keduanya tidak jauh berbeda.
\end{abstract}

Kata kunci: aliran permukaan; beda hingga; MacCormack; numerik; pemodelan; St.Venant.

\begin{abstract}
Rain produces both, surface run off and base flow.In this journal, we will be discussing about developing a software for surface run off modelling based on the Saint Venant equation, using MacCormack 2D methode. The software calculates surface run off over time for 5 differents ground surface profiles, flat, triangular, parabolic and 2 nature profiles. Solution by numerical and analitical are compared for the flat profile. The result shows no significant different for the two methode.
\end{abstract}

Keywords: finite difference; MacCormack; modeling; numeric; run off; St.Venant.

\section{Pendahuluan}

Sungai mempunyai fungsi mengumpulkan curah hujan dalam suatu daerah tertentu dan mengalirkannya ke laut. Daerah dimana sungai memperoleh air merupakan daerah tangkapan hujan yang biasanya disebut Daerah Pengaliran Sungai (DPS), yang dalam konsep lebih luas disebut Daerah Aliran Sungai (DAS). Menurut Sri-Harto [1], DAS merupakan daerah tangkapan yang semua airnya mengalir kedalam suatu alur sungai, daerah ini umumnya dibatasi oleh batas topografi yang jelas dan ditetapkan dengan acuan aliran permukaan.

Menurut Arsyad [2], DAS diartikan sebagai satuan wilayah yang terletak di atas suatu titik pada suatu sungai yang oleh batas-batas topografi mengalirkan air

Makalah diterima redaksi tanggal 15 September 2006, diterima untuk diterbitkan tanggal 15 April 2007. 
yang jatuh di atasnya ke dalam sungai yang sama dan mengalir melalui suatu titik yang sama pada sungai tersebut.

Menurut Sinukaban [3], pemanfaatan sumberdaya alam DAS yang tidak memperhatikan kemampuan dan kelestarian lingkungan, akan terjadi kerusakan ekosistem dan tata guna air. Oleh karena itu dalam membuat perencanaan pengelolaan DAS, pilihan teknologi yang tepat adalah berlandaskan kaidahkaidah konservasi. Karakteristik DAS yang pengaruhnya dominan, meliputi struktur batuan dan geologi, morfometri DAS (bentuk dan luas) DAS), tanah, vegetasi dan tata guna lahan [4].

Untuk memperhitungkan besarnya hujan yang akan memasuki palung sungai sangat tergantung pada kondisi DAS dengan beberapa variabel yang berpengaruh seperti tata guna lahan, jenis penutup, jenis tanah maupun pola curah hujan yang terjadi pada wilayah tersebut.

Disamping itu hujan yang menjadi limpasan pada permukaan DAS secara otomatis akan mengerosi lapisan atas lahan, yang selanjutnya akan dibawa ke palung sungai. Oleh sebab itu untuk memprediksi volume sedimen yang dibawa oleh sungai sangat tergantung kondisi DAS dan pola hujan yang terjadi, disamping karakteristik sungai itu sendiri.

Untuk mengetahui pola aliran yang terjadi pada aliran limpasan permukaan maka perlu dibuat suatu model. Model yang ada dapat berupa model matematik maupun fisik. Dalam penelitian ini digunakan model matematika yang dapat melakukan pemodelan hubungan hujan dan aliran permukaan pada suatu DAS dengan menggunakan asumsi yaitu:

1. Asumsi fluida yang digunakan:

a. Incompressible Fluid (Fluida tak mampu mampat)

b. Irrotational Flow (Aliran tidak berotasi)

2. Persamaan pengatur yang digunakan adalah persamaan St. Venant

3. Penyelesaian differensial waktu yang dilakukan secara eksplisit dengan selisih maju (forward difference) dan penyelesaian differensial ruang digunakan Metoda Selisih Hingga MacCormack.

4. Daerah tangkapan hujan yang ada dibatasi oleh daerah yang kecil

5. Rainfall yang ada seragam

6. Evapotranspirasi dianggap tidak ada. 


\section{Tinjauan Pustaka}

\subsection{Daerah Aliran Sungai (DAS)}

Daerah Aliran Sungai/DAS (catchment, basin, waterhed) merupakan daerah dimana semua airnya mengalir ke dalam suatu sungai yang dimaksudkan. Daerah ini umumnya dibatasi oleh batas topografi, yang berarti ditetapkan berdasarkan aliran air permukaan. Batas ini tidak ditetapkan berdasarkan air bawah tanah karena permukaan air tanah selalu berubah sesuai dengan musim dan tingkat kegiatan pemakaian.

Nama sebuah DAS ditandai dengan nama sungai yang bersangkutan dan dibatasi oleh titik kontrol, yang umumnya merupakan stasiun hidrometri. Dengan memperhatikan hal tersebut berarti suatu DAS dapat merupakan bagian dari DAS lain. Lazimnya apabila terdapat suatu titik kontrol yang dianggap penting, maka DAS ditandai dengan nama pada titik kontrol tersebut, sedangkan titik-titik kontrol lain yang terletak di sebelah hulunya disebutkan sebagai sub-DAS.

Dalam kenyataannya, penetapan batas DAS ini sangat diperlukan untuk menetapkan batas-batas DAS yang akan dianalisis. Penetapan ini mudah dilakukan dari peta topografi untuk bagian sungai di sebelah hulu, akan tetapi untuk bagian-bagian sungai di sebelah hilir, atau dekat pantai relatif sulit dilaksanakan.

\subsection{Daur/Siklus Hidrologi}

Daur/siklus hidrologi adalah suatu proses yang berjalan menerus dari pergerakan air yang dimulai dari laut diangkat (dipindahkan) ke atmosfir turun ke bumi dan kembali lagi ke laut.

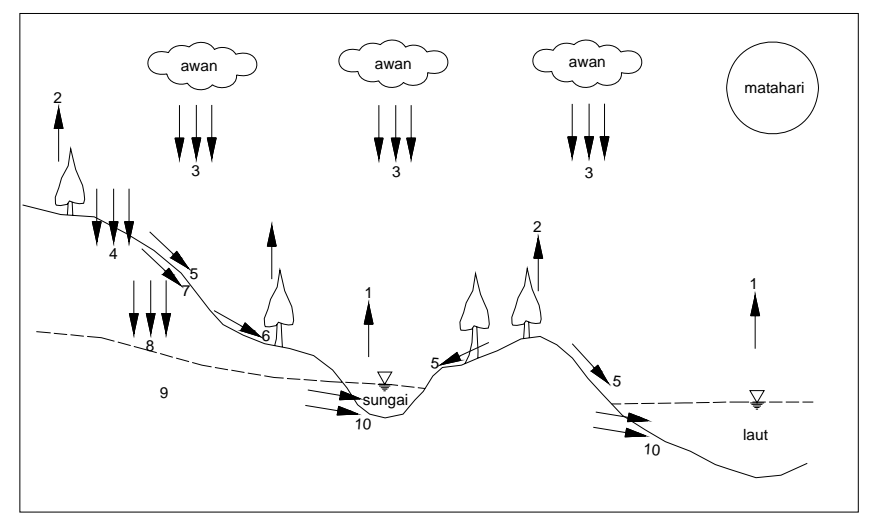

Gambar 1 Siklus hidrologi. 
1. Evaporasi $=$ penguapan dari permukaan ari laut/lautan

2. Transpirasi $=$ penguapan dari vegetasi/tumbuh-tumbuhan

3. Presipitasi $=$ jatuhnya air di permukaan bumi dapat berupa hujan, salju, dan es

4. $\quad$ Infiltrasi $=$ meresapnya air kedalam tanah

5. Aliran permukaan = surface flow $=$ surface runoff

6. Intersepsi $=$ air yang tertahan divegetasi/tumbuhan

7. Interflow $=$ aliran horisontal di bawah permukaan tanah

8. Perkolasi = mengendapnya air didalam tanah

9. Aliran air tanah (Groundwater flow)

10. Eksfiltrasi = keluarnya sebagian aliran bawah permukaan di sungai/laut.

Daur Hidrologi disajikan dalam bentuk diagram kotak (Block Diagram)

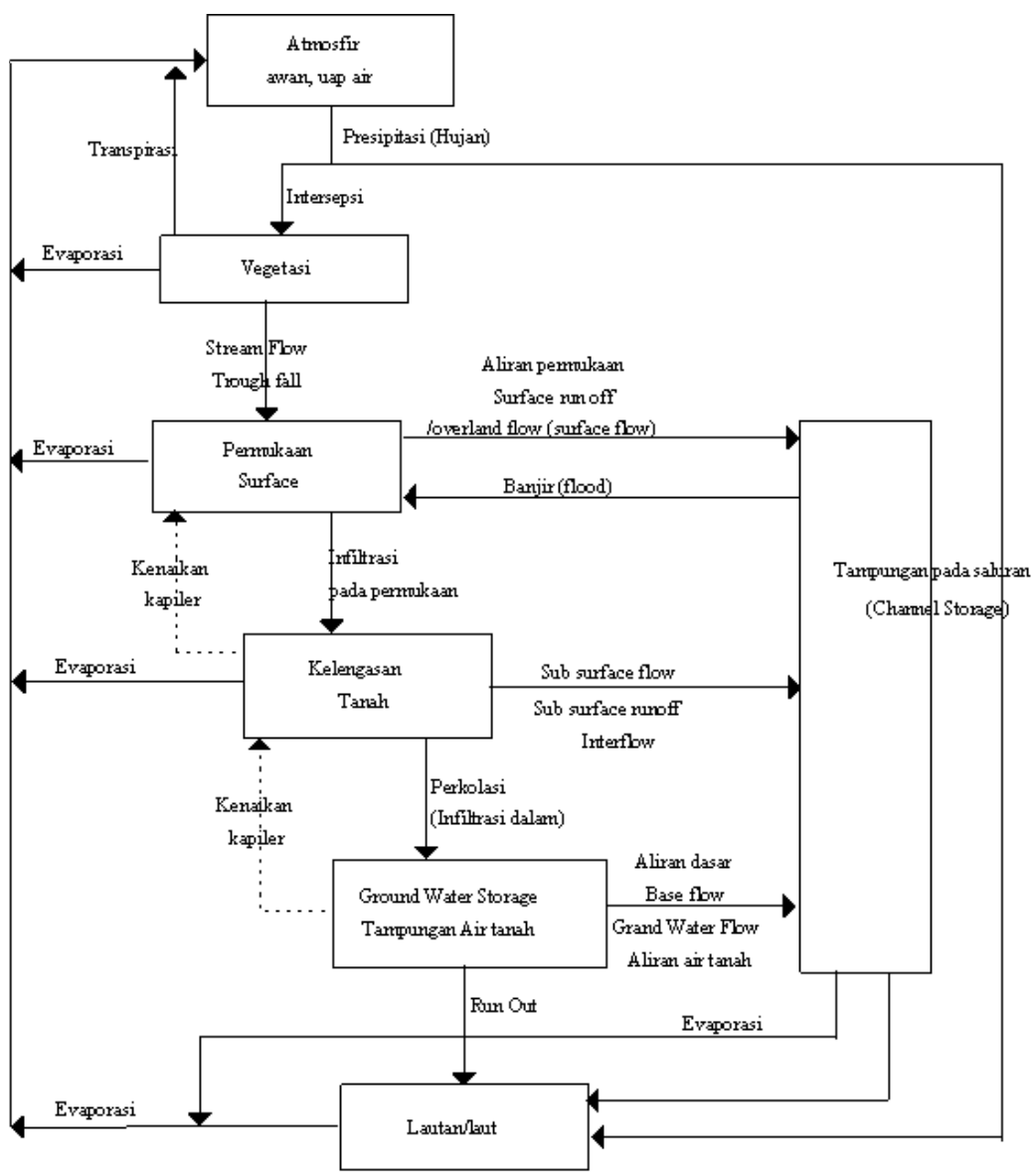

Gambar 2 Diagram blok siklus hidrologi. 


\subsection{Presipitasi}

Istilah hujan yang lebih umum disebut Presipitasi. Presipitasi adalah peristiwa jatuhnya cairan dari atmosfir ke permukaan bumi.

Ada 2 bentuk secara umum daripada Presipitasi:

1. Cair: hujan, embun

2. Beku: salju, hujan es, dan lain-lain.

Faktor-faktor yang mempengaruhi terjadinya presipitasi:

1. Adanya uap air diatmosfir

2. Faktor meteorologi (temperatur, kelembaban, angin)

3. Lokasi daerah sehubungan dengan sistim sirkulasi

4. Adanya rintangan yang disebabkan oleh gunung/pegunungan

5. Faktor geografis.

Bentuk khusus dari Presipitasi

1. Gerimis: tetes cair air yang tipis $\phi<0,5 \mathrm{~mm}$ intensitas $<1 \mathrm{~mm} / \mathrm{jam}$

2. Hujan: tetes air $\phi<0,5 \mathrm{~mm}$

3. Sleet: hujan bercampur es dan salju terdiri dari butir-butir bola es bundar tembus cahaya

4. Salju: salju Campuran kristal es dalam bentuk kompleks hexagonal bercabang, berkumpal, bentuk gumpalan salju merupakan sublinasi atau perubahan langsung dari uap menjadi padat

5. Hujan es: hasil dari hujan badai

6. (thandestorm) hujan berbentuk batues, besar dapat mencapai $0,5 \mathrm{~kg}$ dan diameter berkisar antara $5 \mathrm{~s} / \mathrm{d} 125 \mathrm{~mm}$.

\subsection{Persamaan Aliran Permukaan}

Aliran yang terjadi di alam merupakan aliran 3-dimensi. Dalam pembahasan pada saluran terbuka, banyak faktor yang mempengaruhi diantaranya bentuk geometri, kemiringan dasar saluran, kekasaran dasar dan dinding saluran, besarnya debit dan lain-lain. Hukum kekekalan massa dan momentum digunakan dalam perhitungan saluran terbuka.

Persamaan pengatur untuk simulasi aliran dangkal dua dimensi dapat didekati dengan menggunakan persamaan St. Venant atau hasil penurunan persamaan hidrodinamik di perairan dangkal. Persamaan hidrodinamik ini bermula dari hukum kekekalan massa yang menghasilkan persamaan kontinuitas dan Hukum Newton yang menghasilkan persamaan dasar momentum. 
Air hujan yang jatuh ke bumi akan sampai ke saluran/sungai melalui beberapa macam proses yaitu:

1. Limpasan permukaan (surface runoff)

2. Aliran antara (interflow/subsurface runoff)

3. Aliran air tanah.

Untuk menyederhanakan permasalahan, maka diasumsikan bahwa aliran total hanya dibagi menjadi dua bagian besar, yaitu:

1. Limpasan langsung (direct runoff) yang terdiri dari limpasan permukaan dan interflow.

2. Aliran dasar (base flow) yang sebagian besar terdiri dari air tanah.

\section{$3 \quad$ Pemodelan Numerik}

\subsection{Metoda Penyelesaian Numerik}

Dalam Metoda Numerik dikenal beberapa metoda salah satu diantaranya yaitu Metoda Beda Hingga (Finite Difference Method). Adapun metoda-metoda dalam penyelesaian numerik dapat dikelompokkan seperti pada gambar dibawah:

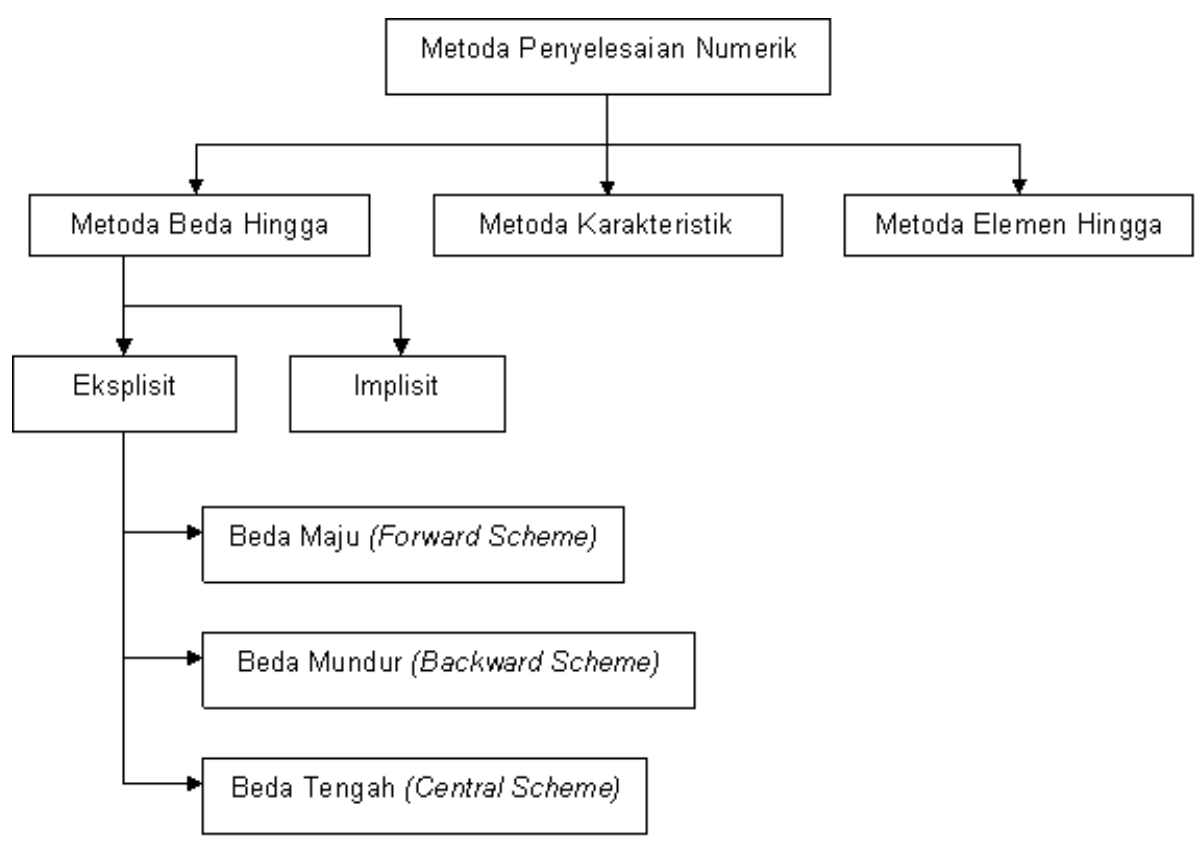

Gambar 3 Metoda Penyelesaian Numerik 
Penyelesaian dengan Metoda Beda Hingga (Finite Difference Method) dapat dibagi menjadi:

1. Cara Eksplisit

Konsep dasar dari Metoda Eksplisit adalah harga variabel pada satu titik level waktu $n+1$ dapat langsung dihitung dari harga pada beberapa titik pada level $n$.

2. Cara Implisit

Konsep dasar dari Metoda Implisit yaitu diskritisasi ruang dilakukan pada level waktu $n+1$ yang akan dicari harganya. Diskritisasi waktu dihitung dengan ekstrapolasi kebelakang. Dengan cara ini untuk setiap langkah waktu akan diperoleh persamaan aljabar simultan.

\subsection{Alur Penyelesaian}

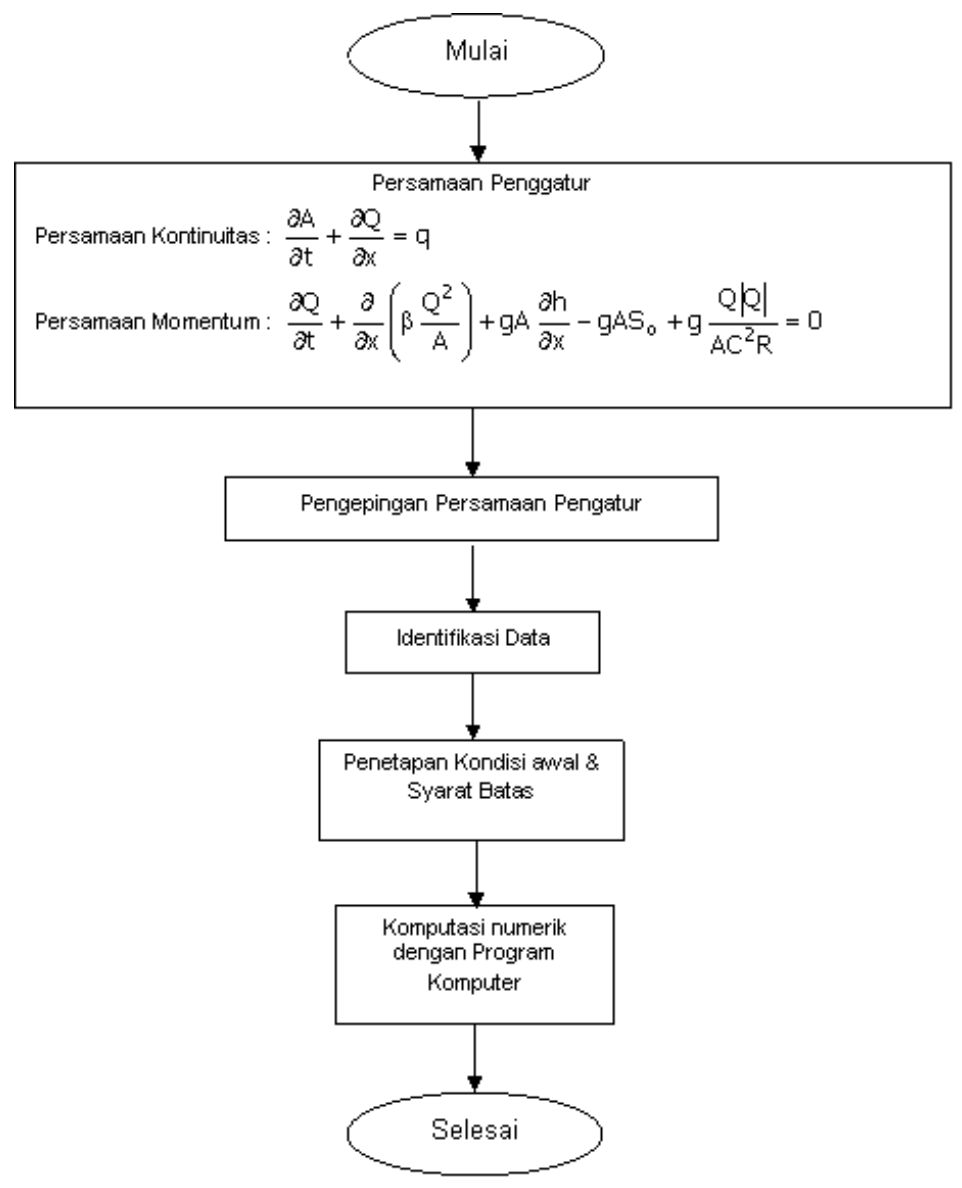

Gambar 4 Bagan Alir Penyelesaian. 


\subsection{Skema Pengepingan MacCormack}

Pada skema MacCormack dikenal langkah Predictor dan Corrector.

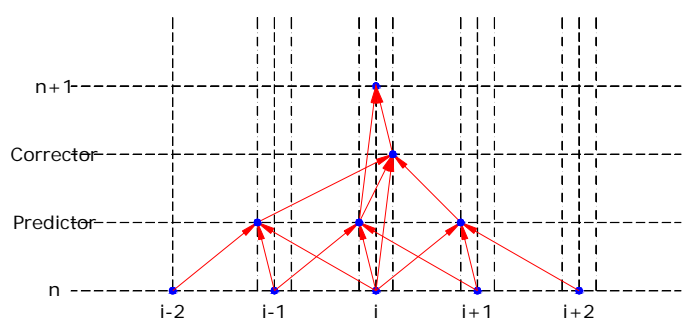

Gambar 5 Skema Pengepingan Explicit MacCormack.

Penerapan skema MacCormack pada Persamaan Aliran 1 Dimensi (Saint Venant Equation) akan menjadi sebagai berikut:

Persamaan Aliran 1 Dimensi (Saint Vernant Equation)

$$
\frac{\partial \mathrm{W}}{\partial \mathrm{t}}+\frac{\partial \mathrm{F}(\mathrm{W})}{\partial \mathbf{x}}+\mathrm{T}(\mathrm{w})=0
$$

Pengepingan persamaan aliran di atas dengan MacCormack memberikan: Predictor:

$$
\widetilde{W}_{i}=W_{i}^{n}-\frac{\Delta t}{\Delta x}\left[F(w)_{i+1}^{n}-F(w)_{i}^{n}\right]-\Delta t T(w)^{n}
$$

\section{Corrector:}

$$
\begin{aligned}
& W_{i}^{\approx}=W_{i}^{n}-\frac{\Delta t}{\Delta x}\left[\widetilde{F}(w)_{i}-\widetilde{F}(w)_{i-1}\right]-\Delta t \widetilde{T}(w) \\
& W_{i}^{n+1}=0.5^{*}\left(W_{\text {predictor }}+W_{\text {corrector }}\right) \\
& W_{i}^{n+1}=\frac{\widetilde{W}_{i}+W_{i}^{\approx}}{2}
\end{aligned}
$$

\subsection{Persamaan St. Venant untuk Aliran Permukaan}

Elemen geometrik yang sederhana digunakan dalam kostruksi fisik model matematika dasar untuk tespon simulasi dari aliran masuk di daerah tangkapan air yang komplek. Panjangnya $L_{0}$ dan kemiringan $S_{0}$, seperti pada gambar dibawah menerima aliran samping ( $\mathrm{r} \mathrm{m} 3 / \mathrm{s} \mathrm{m} 2$ ), hujan. Dari sudut hidrolik, 
daerah ini dapat jdiperhatikan seperti saluran persegi yang lebar. Dalam Pers. St. Venant dapat ditulis:

$$
\frac{\partial h}{\partial t}+\frac{\partial(u h)}{\partial x}=r(x, t) ; \quad \frac{\partial u}{\partial t}+\frac{\partial u}{\partial x}+g \frac{\partial h}{\partial x}=g\left(S_{0}-S_{f}\right)-\frac{r}{h}(u-v) .
$$

\section{Dimana:}

$$
\begin{array}{rlrl}
U & =\text { Kecepatan lokal }(\mathrm{m} / \mathrm{s}) & S_{0} & =\text { Kemiringan dasar saluran } \\
h & =\text { kedalaman local }(\mathrm{m}) & S_{f} & =\text { Kemiringan aliran } \\
r(x, t) & =\text { aliran samping }\left(\mathrm{m}^{3} / \mathrm{s} \mathrm{m}^{2}\right) & V & =\text { Komponen } \mathrm{x} \text { untuk kecepatan } \\
g & =\text { gravitasi }\left(\mathrm{m} / \mathrm{s}^{2}\right) & & \text { dari aliran samping } \\
& X, t & =\text { jarak dan waktu }
\end{array}
$$

Dalam aliran tidak tetap disaluran terbuka, tiga tipe kondisi batas yang digunakan:

1. Dalam kondisi awal, kedalaman dan kecepatan untuk setiap titik pada saluran awal $(t=0)$ sebelum terjadi aliran tidak tetap atau aliran samping.

2. Pada kondisi atas, menentukan pada atas dengan hubungan antara kedalaman dan perubahan atau variasi kedalaman dan perubahan.

3. Pada kondisi bawah menentukan keadaan bawah variasi kedalaman aliran atau perubahan.

Secara computer grid dapat berupa tetap atau tidak, persegi empat atau tidak. Persegi empat yang tetap disukai untuk program computer yang lebih sederhana.

Memperlihatkan bentuk yang khas dalam $(x, t)$. Posisi $x$ ditunjukkan oleh j dan waktu t ditunjukkan oleh n. Jika memperlihatkan fungsi $f(x, t)$, dapat ditunjukkan oleh $f_{j}^{n}$,menyatakan bahwa point $(x, t)$ ditunjukkan oleh $(j, n)$.

Tiga definisi yang umum digunakan untuk menyelesaikan fungsi.

\section{$\underline{\text { Penyelesaian pertama }}$}

$$
\frac{\partial f(x, t)}{\partial t}=\frac{\partial f_{j}^{n}}{\partial t} \approx \frac{f_{j}^{n}-f_{j}^{n-1}}{\Delta t}
$$

yang lebih dikenal dengan operasi kebelakang. $\Delta$ t menerangkan selang waktu.

Penyelesaian kedua digunakan operasi kedepan.

$$
\frac{\partial f(x, t)}{\partial t}=\frac{\partial f_{j}^{n}}{\partial t} \approx \frac{f_{j}^{n+1}-f_{j}^{n}}{\Delta t}
$$


$\underline{\text { Penyelesaian ketiga adalah operasi tengah }}$

$$
\frac{\partial f(x, t)}{\partial t}=\frac{\partial f_{j}^{n}}{\partial t} \approx \frac{f_{j}^{n+1}-f_{j}^{n-1}}{2 \Delta t}
$$

Sebagai contoh untuk operasi tengah, tingkat kedua dapat ditulis:

$$
\frac{\partial^{2} f(x, t)}{\partial t}=\frac{\partial^{2} f_{j}^{n}}{\partial t^{2}} \approx \frac{f_{j}^{n+2}-2 f_{j}^{n}+f_{j}^{n-2}}{(2 \Delta t)^{2}}
$$

untuk operasi kedepan

$$
\frac{\partial^{2} f_{j}^{n}}{\partial t^{2}} \approx \frac{f_{j}^{n+2}-2 f_{j}^{n+1}+f_{j}^{n}}{(2 \Delta t)^{2}}
$$

untuk operasi kebelakang

$$
\frac{\partial^{2} f_{j}^{n}}{\partial t^{2}} \approx \frac{f_{j}^{n}-2 f_{j}^{n-1}+2 f_{j}^{n-2}}{(2 \Delta t)^{2}}
$$

\subsection{Explicit Numerical Schemes}

\section{MacCormack Scheme}

Dengan menggunakan bentuk konservatif persamaan ST Venant yaitu:

$$
U_{t}+W_{R}+R=0
$$

dimana:

$$
U=\left[\begin{array}{c}
A \\
U A
\end{array}\right] ; \quad \mathrm{W}=\left[\begin{array}{l}
\mathrm{UA} \\
\left(\mathrm{g} \frac{\mathrm{Y}_{\mathrm{m}}}{2}+U^{2}\right) A
\end{array}\right] \quad \mathrm{R}=\left[\begin{array}{l}
-\mathrm{r}(\mathrm{x}, \mathrm{t}) \mathrm{b} \\
-\left(\mathrm{g} \frac{\mathrm{Y}_{\mathrm{m}}}{2}+U^{2}\right) A
\end{array}\right]
$$

dimana:

$$
\begin{array}{lll}
Y_{m} & =\text { kedalaman aliran rata-rata } & Q=V A \\
B & =\text { lebar saluran } &
\end{array}
$$

Langkah predictor digunakan seperti langkah kebelakang.

$$
U_{j}^{*}=U_{j}^{n}-\frac{\Delta t}{\Delta x}\left(W_{j}^{n}-W_{j-1}^{n}\right)-\Delta t R_{j}^{n} \quad 2 \leq \mathrm{J} \leq N
$$

Langkah korektor digunakan seperti langkah kedepan: 


$$
U_{j}^{* *}=U_{j}^{*}-\frac{\Delta t}{\Delta x}\left(W_{j+1}^{*}-W_{j}^{*}\right)-\Delta t R_{j}^{*} \quad 1 \leq \mathrm{J} \leq N
$$

untuk penyelesaiannya:

$$
U_{j}^{n+1}=\frac{1}{2}\left(U_{j}^{*}+U_{j}^{* *}\right)
$$

untuk Stabilitas:

$$
\Delta t=C_{n} \frac{\Delta x}{\max (|u|+g \sqrt{g h})} .
$$

\section{$\underline{\text { Solusi Numerik Gelombang Kinematik }}$}

Persamaan kontinuitas dan momentum dapat dikombinasikan pada persamaan dibawah ini, berlaku untuk non linier, satu dimensi dan persamaan differensial. Persamaan dibawah ini dapat dengan mudah menyelesaikan numerik untuk $y=f$ $(x, t, i-f)$. Ketika y ditemukan, dan disubtitusikan menghasilkan aliran per unit lebar dari aliran limpasan permukaan (cfs/ft).

$$
\frac{\partial y}{\partial t}+\partial y^{m-1} \frac{\partial y}{\partial x}=i-f ; \quad q=V y=\partial y^{m} ; c=\frac{3}{2} V .
$$

Kasus yang lebih umum adalah menyelesaikan untuk $A(x, t)$, termasuk kedalaman dari aliran limpasan permukaan. Model ini dapat ditemukan pada kasus saluran ekstrim dan kasus daerah tangkapan ekstrim.

$$
\frac{\partial A}{\partial t}+\alpha \frac{\partial A^{m}}{\partial x}=\bar{q} \quad ; \quad Q=\alpha A^{m} .
$$

\section{Aplikasi untuk gelombang kinematik aliran limpasan permukaan}

Implementasi persamaan kinematik terhadap program numeric FOTRAN dapat dilihat sebagai berikut:

$\mathrm{I}=1$ titik batas atas

$\mathrm{I}=\mathrm{N} 1$ titik batas bawah

\section{Langkah Predictor}

Untuk semua titik (2.... N1-1):

$$
y p(i)=y(i)-\alpha \frac{\Delta t}{\Delta x} y(i)^{m}+\alpha \frac{\Delta t}{\Delta x} y(i-1)^{m}+(i-f) \Delta t
$$




\section{Langkah Corrector}

Untuk semua titik (2... N1-1):

$$
\text { yc(i) }=\text { yp(i) }-\alpha \frac{\Delta t}{\Delta x} y p(i-1)^{m}+\alpha \frac{\Delta t}{\Delta x} y p(i)^{m}+(i-f) \Delta t
$$

Harga di langkah waktu selanjutnya:

Untuk semua titik (2... N1-1)

$$
y n(i)=0,5[y(i)+y c(i)]
$$

Solusi Numerik Gelombang Diffusi

Persamaan gelombang diffuse untuk perhitungan aliran limpasan permukaan adalah:

$$
\frac{\partial y}{\partial t}+c \frac{\partial y}{\partial x}=K_{1} \frac{\partial^{2} y}{\partial x^{2}}+(i-f)
$$

dimana:

$$
c=\left(\frac{5}{3} V\right) ; \quad K_{1}=\frac{V y}{2 S_{0}}=\frac{q}{2 S_{0}}
$$

Aplikasi untuk gelombang Diffusi Aliran Limpasan Permukaan

Implementasi persamaan dalam Program FOTRAN dapat dilihat sebagai berikut:

I $\quad 1$ titik batas atas

I = N1 titik batas bawah

$$
d g=d t * \frac{60}{(1 * d x)} ; d g 1=d t * \frac{60}{(d x * d x)}
$$

\section{Langkah Predictor}

Untuk semua titik di dalam (2....N1-1):

$h p(i)=h(i)-d g * c *(h(i+1)-h(i))+d g 1 * k_{1} *(h(i+1)-2 h(i)+h(h-1))+q b a r * d t * 60$

Kemudian masukkan kondisi batas pada $\mathrm{I}=1$ dan $\mathrm{I}=\mathrm{N} 1$. 


\section{$\underline{\text { Langkah Corrector }}$}

Untuk semua titik di dalam (2...N1-1)

$h c(i)=h p(i)-d g * c *(h p(i)-h p(i-1))+d g 1 * k_{1} *(h p(i+1)-2 h(i)+h p(i-1))+q b a r * d t * 60$

Hasil pada saat langkah waktu selanjutnya:

Untuk semua titik di dalam (2...N1-1):

$$
h n(i)=0.5[h(i)+h c(i)]
$$

\subsection{Metode Selisih Hingga}

\section{Metode Selisih Hingga MacCormack 1 D}

Penilaian obyektif untuk penyelesaian numerik adalah dengan menghitung untuk $\mathrm{A}(\mathrm{x}, \mathrm{t})$ pada setiap titik pada grid $\mathrm{x}$-t, memberikan parameter dan $\mathrm{m}$, dan juga inisial dan kondisi batas.

Pada kenyataannya, kita memperhatikan hasil dari $A(x=L, t)$. Bentuk Finite Difference untuk luas dan waktu dijelaskan sebagai:

$$
\frac{\partial A}{\partial x} \approx \frac{A_{i+1}^{j+1}-A_{i}^{j+1}}{\Delta x} ; \quad \frac{\partial A}{\partial t} \approx \frac{A_{i+1}^{j}-A_{i}^{j+1}}{\Delta t}
$$

Untuk mendapat persamaan linier, hasil dari $A$ digunakan dalam $\left(\alpha m A^{m-1}\right)$ berasal dari rata-rata hasil silang diagonal; sehingga fungsi linier dapat diketahui hasil A:

$$
A_{*} \approx \frac{A_{i+1}^{j}-A_{i}^{j+1}}{2}
$$

Hasil dari pengaruh hujan $(I-f)=q$ (menjadi aliran samping untuk kasus saluran).

$$
\bar{q}=\frac{q_{i+1}^{j+1}-q_{i+1}^{j}}{2}
$$

Sehingga diperloleh persamaan linier gelombang kinematik untuk metode finite difference adalah:

$$
\frac{A_{i+1}^{j+1}-A_{i+1}^{j}}{\Delta t}+\alpha\left[\frac{\left(A_{i+1}^{j+1}\right)^{m}-\left(A_{i+1}^{j}\right)^{m}}{\Delta x}\right]=\frac{q_{i+1}^{j+1}-q_{i+1}^{j}}{2}=\bar{q}
$$


Penyelesaian eksplisit untuk harga A yang tidak diketahui:

$$
A_{i+1}^{j+1}=\bar{q} \Delta t+A_{i+1}^{j}\left[1-\alpha \frac{\Delta t}{\Delta x}\left(A_{i+1}^{j}\right)^{m-1}\right]+\frac{\alpha \Delta t}{\Delta x}\left(A_{i}^{j}\right)^{m}
$$

Untuk kondisi batas diberikan:

$$
\Delta t \leq \frac{\Delta x}{C_{k}}
$$

Dimana $\mathrm{C}_{\mathrm{k}}=$ koefisien gelombang kinematik

$$
\begin{aligned}
& \mathrm{C}_{\mathrm{k}}=\alpha \mathrm{m}\left(\mathrm{A}_{*}\right)^{\mathrm{m}-1} ; \theta=\alpha m A_{*}^{m-1} \frac{\Delta t}{\Delta x} \leq 1 ; \frac{A_{i}^{j+1}-A_{i 1}^{j}}{\Delta t}+\alpha\left[\frac{Q_{i+1}^{j+1}-Q_{i}^{j+1}}{\Delta x}\right]=\bar{q} ; \\
& Q_{i+1}^{j+1}=\bar{q} \Delta x+Q_{i}^{j+1}-\frac{\Delta x}{\Delta t}\left(A_{i}^{j+1}-A_{i}^{j}\right) ; \quad A_{i+1}^{j+1}=\left(\frac{Q_{i+1}^{j+1}}{\alpha}\right)^{\frac{1}{m}}
\end{aligned}
$$

\section{Metode Selisih Hingga 2D}

Pada pemodelan satu dimensi suatu fungsi elevasi muka air $(H(x, t)$ adalah fungsi dua kisaran bebas x dan t dengan domain pada bidang domain $\Omega$ (omega) dalam koordinat karetesian. Untuk dua dimensi ada penambahan fungsi pada sumbu $-y$ sehingga fungsi elevasi muka air menjadi $H_{i}(x, y, t)$, yaitu tiga fungsi besaran bebas $x, y$ dan $t$. Selanjutnya domain $\Omega$ dibagi-bagi membentuk kisi-kisi dengan panjang sisi-sisi $\Delta x, \Delta y$ dan $\Delta t$. Biasanya $\Delta x, \Delta y$ dan $\Delta t$ tidak harus selalu seragam dimana nilai $\Delta x, \Delta y$ atau $\Delta t$ dapat berbeda-beda untuk setiap pasangan titik gridnya.

Wilayah domain $\Omega$ dibagi menjadi kisi-kisi dengan panjang kisi tetap yaitu dalam arah sumbu- $x$ adalah $\Delta x$ dan sumbu- $y$ adalah $\Delta y$ serta dalam arah sumbu- $t$ adalah $\Delta t$. Pada cara selisih hingga kita hanya mencari pendekatan nilai-nilai $h_{i}$ di titik-titik kisi. Nilai $h_{i}$ ataupun turunannya pada suatu titik tertentu pada wilayah domain $\Omega$ dapat dianggap sebagai harga pendekatan atau sebagai fungsi dari nilai-nilai h dititik-titik kisi disekitarnya.

Penurunan persamaan aliran yang sering dipakai oleh dalam metode selisih hingga adalah suatu persamaan matematika yang dikenal sebagai deret Taylor berikut: 


$$
\begin{aligned}
& f\left(x_{0}+\Delta x\right)=f\left(x_{0}\right)+\Delta x \frac{\partial f\left(x_{0}\right)}{\partial x}+\frac{(\Delta x)^{2}}{2 !} \frac{\partial^{2} f\left(x_{0}\right)}{\partial x^{2}}+\frac{(\Delta x)^{3}}{3 !} \frac{\partial^{3} f\left(x_{0}\right)}{\partial x^{3}}+\ldots \\
& =f\left(x_{0}\right)+\sum_{n=1}^{\infty} \frac{(\Delta x)^{n}}{n !} \frac{\partial^{n} f\left(x_{0}\right)}{\partial x^{n}}
\end{aligned}
$$

Misal kecepatan longitudinal $u$ merupakan fungsi $x$, jika harga $u$ pada $x=x_{i}$ hadala $u_{i}$ dan harga $u$ pada $x=x_{i+1}$ adalah $u_{i+1}$ maka dengan deret Taylor diperoleh:

$$
u_{i+1, j}=u_{i, j}+\left(\frac{\partial u}{\partial x}\right) \Delta x+\left(\frac{\partial^{2} u}{\partial x^{2}}\right) \frac{\Delta x^{2}}{2 !}+\left(\frac{\partial^{3} u}{\partial x^{3}}\right) \frac{\Delta x 3}{3 !}+\left(\frac{\partial^{4} u}{\partial x^{4}}\right) \frac{\Delta x^{4}}{4 !}+\ldots+\left(\frac{\partial^{n} u}{\partial x^{n}}\right) \frac{\Delta x^{n}}{n !}
$$

Kecepatan transversal $v$ merupakan fungsi $y$, jika harga $v$ pada $y=y_{i}$ adalah $v_{i}$ dan harga $v$ pada $y=y_{i+1}$ adalah $v_{i+1}$ maka dengan deret Taylor diperoleh:

$$
v_{i+1, j}=v_{i, j}+\left(\frac{\partial v}{\partial x}\right) \Delta y+\left(\frac{\partial^{2} v}{\partial y^{2}}\right) \frac{\Delta y^{2}}{2 !}+\left(\frac{\partial^{3} v}{\partial y^{3}}\right) \frac{\Delta y^{3}}{3 !}+\left(\frac{\partial^{4} v}{\partial y^{4}}\right) \frac{\Delta y^{4}}{4 !}+\ldots+\left(\frac{\partial^{n} v}{\partial y^{n}}\right) \frac{\Delta y^{n}}{n !}
$$

Persamaan di atas dapat ditulis sebagai berikut:

$$
\begin{aligned}
& \left(\frac{\partial u}{\partial x}\right)=\frac{u_{i+1, j}-u_{i, j}}{\Delta x}-\left(\frac{\partial^{2} u}{\partial x^{2}}\right) \frac{\Delta x}{2 !}+\left(\frac{\partial^{3} u}{\partial x^{3}}\right) \frac{\Delta x^{2}}{3 !}+\left(\frac{\partial^{4} u}{\partial x^{4}}\right) \frac{\Delta x^{3}}{4 !}+\ldots+\left(\frac{\partial^{n} u}{\partial x^{n}}\right) \frac{\Delta x^{n-1}}{n !} \\
& \left(\frac{\partial v}{\partial x}\right)=\frac{v_{i+1, j}-v_{i, j}}{\Delta y}-\left(\frac{\partial^{2} v}{\partial y^{2}}\right) \frac{\Delta y}{2 !}+\left(\frac{\partial^{3} v}{\partial y^{3}}\right) \frac{\Delta y^{2}}{3 !}+\left(\frac{\partial^{4} v}{\partial y^{4}}\right) \frac{\Delta y^{3}}{4 !}+\ldots+\left(\frac{\partial^{n} v}{\partial y^{n}}\right) \frac{\Delta y^{n-1}}{n !}
\end{aligned}
$$

Persamaan ini adalah deret Taylor tingkat tinggi (high order) dengan pola $(\Delta x)^{n}$ dan $(\Delta y)^{\mathrm{n}}$ yang menunjukkan tingkatannya. Pada pendiskritisasian dua dimensi atau kecepatan $u(x, y)$, persamaan tersebut dapat ditulis sebagai berikut:

Harga selisih maju level pertama (first order forward difference)

$$
\left(\frac{\partial u}{\partial x}\right)_{i, j}=\frac{u_{i+1, j}-u_{i, j}}{\Delta x}+O(\Delta x) ;\left(\frac{\partial v}{\partial y}\right)_{i, j}=\frac{v_{i+1, j}-v_{i, j}}{\Delta y}+O(\Delta y)
$$

Harga selisih mundur level pertama (first order backward difference)

$$
\left(\frac{\partial u}{\partial x}\right)_{i, j}=\frac{u_{i, j}-u_{i-1, j}}{\Delta x}+O(\Delta x) ;\left(\frac{\partial v}{\partial y}\right)_{i, j}=\frac{v_{i+1, j}-v_{i-1, j}}{\Delta y}+O(\Delta y)
$$

Harga selisih pusat level kedua (second order central difference) 


$$
\begin{aligned}
& \left(\frac{\partial u}{\partial x}\right)_{i, j}=\frac{u_{i+1, j}-u_{i-1, j}}{2 \Delta x}+O(\Delta x)^{2}\left(\frac{\partial^{2} u}{\partial x^{2}}\right)_{i, j}=\frac{u_{i+1, j}-2 u_{i, j}+u_{i-1, j}}{(\Delta x)^{2}}+O(\Delta x)^{2} \\
& \left(\frac{\partial^{2} v}{\partial y^{2}}\right)_{i, j}=\frac{v_{i+1, j}-2 v_{i, j}+v_{i-1, j}}{(\Delta y)^{2}}+O(\Delta y)^{2} .
\end{aligned}
$$

\subsection{Metode MacCormack Eksplisit}

Persamaan pengatur St. Venant dalam bentuk unsteady melibatkan diferensial waktu dan diferensial ruang. Diferensial waktu ini diselesaikan dengan cara eksplisit dan diferensial ruang dengan metode selisih hingga MacCormack.

Pada cara selisih hingga eksplisit, setelah bentuk pendekatan turunan diisikan pada persamaan diferensial, harga fungsi waktu suatu titik kisi pada selang waktu $t=t+\Delta t$ sepanjang sumbu- $x$ dan sumbu- $y$ dapat dihitung langsung dengan memakai nilai-nilai fungsi di titik didekatnya pada selang waktu $t=\Delta t$ yang sudah diketahui.Pengembangan secara eksplisit mempunyai kelemahan, karena itu untuk mendapatkan kemantapan perhitungan diperlukan pembatasan selang waktu $\Delta \mathrm{t}$.

Secara umum skema numeric MacCormack eksplisit dibagi dalam dua tahap yaitu tahap prediktor dan tahap korektor. Untuk lebih jelasnya dapat dilihat persamaan diferensial parsial linier berikut:

$$
\frac{\partial U}{\partial t}=-\frac{\partial U}{\partial x}-\frac{\partial U}{\partial y}
$$

Dengan menggunakan skema numerik MacCormack, persamaan dapat didekati dalam dua tahap, pertama tahap prediktor menggunakan selisih maju, yaitu:

$$
\frac{u_{i, j}^{*}-u_{i, j}^{n}}{\Delta t}=\frac{u_{i+1, j}^{n}-u_{i, j}^{n}}{\Delta x}-\frac{u_{i, j+1}^{n}-u_{i, j}^{n}}{\Delta y}
$$

dimana:

* $\quad=$ menunjukkan harga sementara

$i, j \quad=$ titik grid pada arah- $x$ dan arah- $y$

$\Delta t \quad=$ besar step waktu

$n \quad=$ posisi waktu

$\Delta x, \Delta y=$ besar step ruang

Langkah selanjutnya adalah tahap korektor menggunakan selisih mundur yaitu: 


$$
\frac{u_{i, j}^{n+1}-u_{i, j}^{n+1 / 2}}{1 / 2 \Delta t}=\frac{u_{i+1, j}^{*}-u_{i, j}^{*}}{\Delta x}-\frac{u_{i, j+1}^{*}-u_{i, j}^{*}}{\Delta y}
$$

Dimana $U_{i, j}^{n+1 / 2}$ adalah harga rata-rata yang dihitung dari:

$$
U_{i, j}^{n+1 / 2}=\frac{1}{2}\left(U_{i, j}^{*}+U_{i, j}^{*}\right)
$$

Secara ringkas metode numerik MacCormack eksplisit dapat ditulis menjadi sebagai berikut:

\section{Tahap Prediktor}

$$
\begin{aligned}
& \frac{\partial U}{\partial t}=\frac{U_{i, j}^{*}-U_{i, j}^{n}}{\Delta t} ; \frac{\partial U}{\partial x}=\frac{U_{i+1, j}^{n}-U_{i, j}^{n}}{\Delta x} ; \frac{\partial U}{\partial y}=\frac{U_{i, j+1}^{n}-U_{i, j}^{n}}{\Delta y} \\
& P U_{i, j}=U_{i, j}^{n}-\frac{\Delta t}{\Delta x} \cdot\left(F_{i+1, j}^{n}-F_{i, j}^{n}\right)-\frac{\Delta t}{\Delta y} \cdot\left(G_{i, j+1}^{n}-G_{i, j}^{n}\right)+\Delta t \cdot S_{i, j}^{n}
\end{aligned}
$$

Tahap Korektor

$$
\begin{aligned}
& \frac{\partial U}{\partial t}=\frac{C U_{i, j}-P U_{i, j}}{\Delta t} ; \frac{\partial U}{\partial x}=\frac{P U_{i, j}-P U_{i-1, j}}{\Delta x} ; \frac{\partial U}{\partial y}=\frac{P U_{i, j}-P U_{i, j-1}}{\Delta y} \\
& C U_{i, j}=P U_{i, j}-\frac{\Delta t}{\Delta x} \cdot\left(P F_{i+1, j}-P F_{i, j}\right)-\frac{\Delta t}{\Delta y} \cdot\left(P G_{i, j+1}-P G_{i, j}\right)+\Delta t \cdot P S_{i, j}
\end{aligned}
$$

Tahap Penyelesaian

$$
U_{i, j}^{n+1}=\frac{1}{2}\left(P U_{i, j}+C U_{i, j}\right)
$$

Untuk masalah non-linier sebenarnya tidak ada skema khusus yang dapat dipakai, tetapi dengan menggunakan pendekatan masalah linier permasalahan non-linier dapat dipecahkan.

\section{Penerapan Metode MacCormack Pada Persamaan Gelombang Kinematik}

Persamaan pengatur dalam bentuk unsteady melibatkan diferensial waktu dan ruang, penyelesaian diferensial waktu dilakukan secara eksplisit dengan selisih maju sedangkan diferensial ruang diselesaikan dengan MacCormack.

\section{Persamaan Aliran Limpasan Permukaan}

\section{Persamaan Kontinuitas}




$$
\frac{\partial}{\partial t}[H]+\frac{\partial}{\partial x}[H U]+\frac{\partial}{\partial y}[H V]=S
$$

\section{Persamaan Momentum}

Arah- $x$ :

$$
g H \frac{\partial(h+z)}{\partial x}=\left[-g H S_{f x}\right]
$$

Arah-y

$$
g H \frac{\partial(h+z)}{\partial y}=\left[-g H S_{f y}\right]
$$

Dalam bentuk matriks persamaan tersebut dapat ditulis menjadi:

$$
\frac{\partial}{\partial t}\left[\begin{array}{c}
H \\
0 \\
0
\end{array}\right]+\frac{\partial}{\partial x}\left[\begin{array}{c}
U H \\
g H^{2} \\
0
\end{array}\right]+\frac{\partial}{\partial y}\left[\begin{array}{c}
V H \\
0 \\
g H^{2}
\end{array}\right]=\left[\begin{array}{c}
R F \\
-g H S_{f x} \\
-g H S_{f y}
\end{array}\right]
$$

Persamaan St. Venant 2D pada koordinat cartesius dalam bentuk nondimensional dapat ditulis secara simbolis sebagai berikut:

$$
\frac{\partial Q}{\partial t}+\frac{\partial F}{\partial x}+\frac{\partial G}{\partial y}=S
$$

dimana:

$$
Q=\left[\begin{array}{c}
H \\
0 \\
0
\end{array}\right] ; \quad F=\left[\begin{array}{c}
U H \\
g H^{2} \\
0
\end{array}\right] ; \quad G=\left[\begin{array}{c}
V H \\
0 \\
g H^{2}
\end{array}\right] ; \quad S=\left[\begin{array}{c}
R F \\
-g H S_{f x} \\
-g H S_{f y}
\end{array}\right]
$$

dimana:

$$
\begin{array}{lll}
H=\text { komponen elevasi muka air } & S_{0 y}=\text { kemiringan dasar saluran arah- } y \\
U=\text { komponen kecepatan arah- } x & S_{f x}=\text { gesekan dasar saluran arah- } x \\
V=\text { kompenen kecepatan arah- } y & S_{f y}=\text { gesekan dasar saluran arah- } y \\
g & =\text { percepatan gravitasi } & R F=\text { hujan rata-rata } \\
S_{0 x}=\text { kemiringan dasar saluran arah- } x &
\end{array}
$$

$$
S_{f x}=\frac{n^{2} U \sqrt{U^{2}+V^{2}}}{h^{4 / 3}} ; \quad S_{f y}=\frac{n^{2} V \sqrt{U^{2}+V^{2}}}{h^{4 / 3}}
$$


$\underline{\text { Penyelesaian dengan Metode MacCormack Eksplisit }}$

Persamaan kontinuitas dan persamaan momentum dua dimensi merupakan persamaan diferensial parsial non-linier dalam ruang dan waktu. Pada dasarnya tidak ada skema khusus untuk menyelesaikan persamaan diferensial parsial non-linier tetapi dengan menggunakan pendekatan penyelesaian persamaan linier, maka persamaan tersebut dapat dipecahkan.

Penerapan metode selisih hingga MacCormack dapat digunakan untuk menyelesaikan persamaan St. Venant dua dimensi tersebut. Untuk menjelaskan hal ini, persamaan ditulis dalam bentuk simbolis berikut:

$$
\frac{\partial Q}{\partial t}+\frac{\partial F}{\partial x}+\frac{\partial G}{\partial y}=S
$$

Persamaan ini dapat ditulis menjadi:

$$
\frac{\partial Q}{\partial t}=-\frac{\partial F}{\partial x}-\frac{\partial G}{\partial y}+S
$$

Persamaan di atas dapat didekati dengan metode selisih hingga MacCormack menjadi sebagai berikut:

\section{$\underline{\text { Tahap Prediktor }}$}

$$
P \bar{Q}_{i, j}=Q_{i, j}^{n}-\Delta t\left[\frac{Q_{i+1, j}^{n}-Q_{i, j}^{n}}{\Delta x}+\frac{Q_{i, j+1}^{n}-Q_{i, j}^{n}}{\Delta y}\right]+\Delta t Q b a r
$$

Tahap Korektor

$$
C Q_{i, j}=P \bar{Q}_{i, j}^{n}-\Delta t\left[\frac{Q_{i+1, j}^{-n}-Q_{i, j}^{-n}}{\Delta x}+\frac{Q_{i, j+1}^{-n}-Q_{i, j}^{-n}}{\Delta y}\right]+\Delta t Q b a r
$$

\section{Penyelesaian}

$$
\bar{Q}_{i, j}^{n+1}=\frac{1}{2}\left(P \bar{Q}_{i, j}+C \bar{Q}_{i, j}\right)
$$

dimana:

$$
\begin{aligned}
& \mathrm{Q}_{\mathrm{i}+1, \mathrm{j}}=(\mathrm{UH})_{\mathrm{i}+1, \mathrm{j}} \quad ; \quad \mathrm{Q}_{\mathrm{i}, \mathrm{j}+1}=(\mathrm{VH})_{\mathrm{i}, \mathrm{j}+1} \\
& u=-\frac{h^{\frac{2}{3}}}{n \sqrt{S_{f}}} \frac{\partial H}{\partial x}=-\frac{K}{h} \frac{\partial H}{\partial x} ; u=-\frac{h^{\frac{2}{3}}}{n \sqrt{S_{f}}} \frac{\partial H}{\partial y}=-\frac{K}{h} \frac{\partial H}{\partial y}
\end{aligned}
$$

dimana: 


$$
K=-\frac{h^{\frac{2}{3}}}{n \sqrt{S_{f}}} \text { untuk }\left|S_{f}\right|>\delta \text { dan } h>h \text { min ; K=0 untuk yang lainnya. }
$$

Persamaan dapat ditulis dengan seperti di bawah

$$
\frac{\partial H}{\partial t}=\frac{\partial}{\partial x}\left(K \frac{\partial H}{\partial x}\right)+\frac{\partial}{\partial y}\left(K \frac{\partial H}{\partial y}\right)
$$

$K=$ tekanan konduksi hidrolik pada persamaan aliran

\section{$4 \quad$ Studi Kasus}

Studi kasus akan dilakukan pada 5 profil topografi lahan, yaitu:

1. Profil datar

2. Profil cekungan segitiga

3. Profil cekungan parabolik

4. Profil alam 1

5. Profil alam 2

\subsection{Profil Datar}
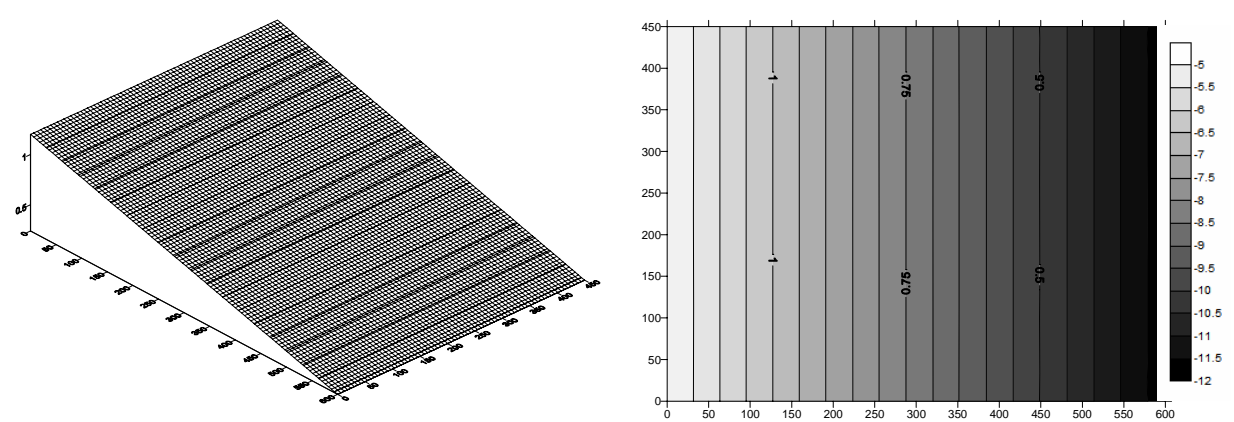

Gambar 6 Profil datar.

Solusi analitik untuk profil datar adalah sebagai berikut:

$$
I_{0}=h_{\text {yet }} ; \alpha=\frac{1.49}{C M} \sqrt{S_{0}} ; t_{s}=\left(\frac{L}{\alpha i_{0}{ }^{m-1}}\right)^{1 / m}
$$

Untuk $t>t p$ :

$$
L=\frac{q}{i_{0}}+m q^{\left(1-\frac{1}{m}\right)} \alpha^{\frac{1}{m}}(t-t p)
$$


Data-data yang digunakan:

\begin{tabular}{|c|c|c|c|}
\hline$N$ & $=0,025$ & $D T$ & $=0,001$ menit \\
\hline$H_{\text {yet }}$ & $=2$ inch/hour dengan durasi 30 menit & $S_{0}$ & $=0,0016$ \\
\hline
\end{tabular}

Hasil perhitungan numerik menunjukkan perubahan kontur permukaan air dan arah aliran yang dapat dilihat pada gambar dibawah ini.

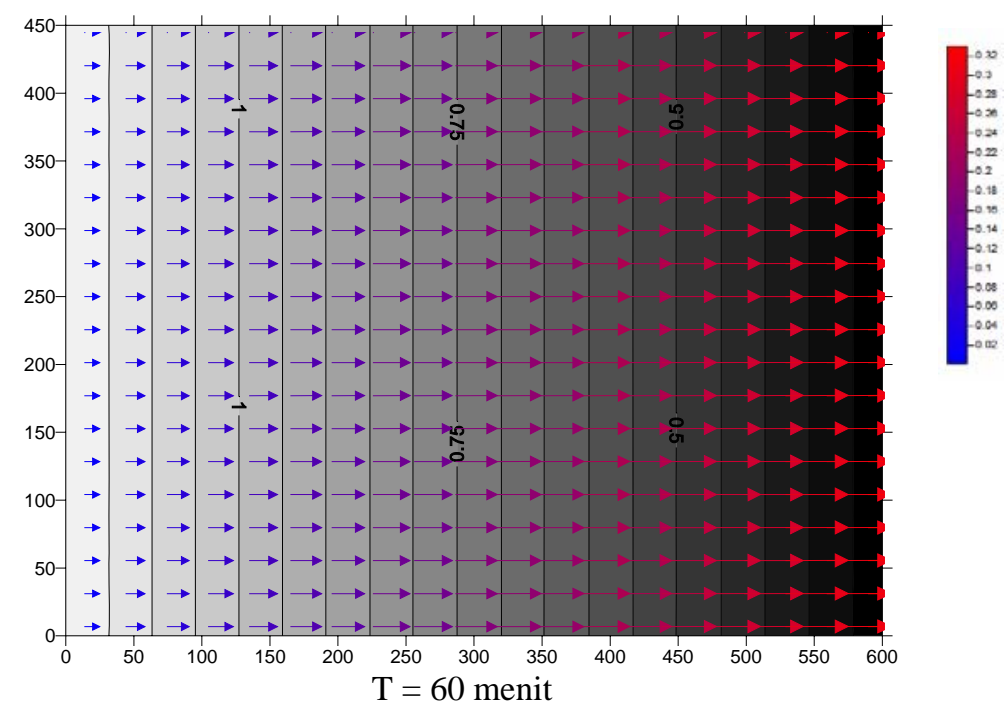

Gambar 7 Profil kecepatan dan kedalaman terhadap waktu.

Pada profil datar ini dilakukan perbandingan antara solusi analitik dengan solusi numerik 1D dan 2D.

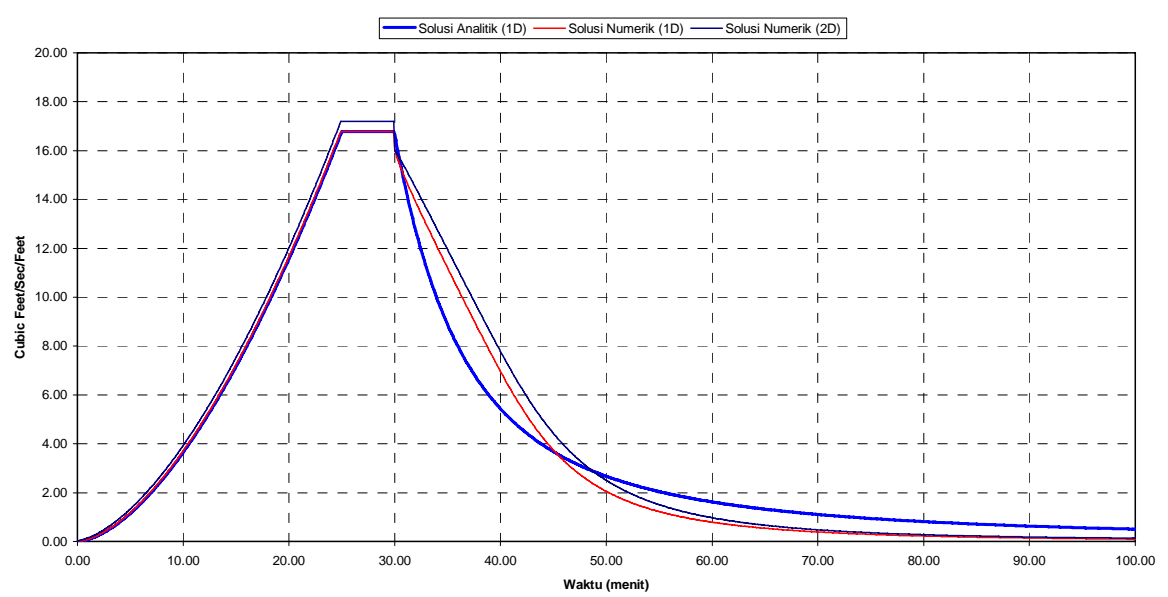

Gambar 8 Perbandingan solusi analitik dan numerik. 


\subsection{Profil Segitiga}
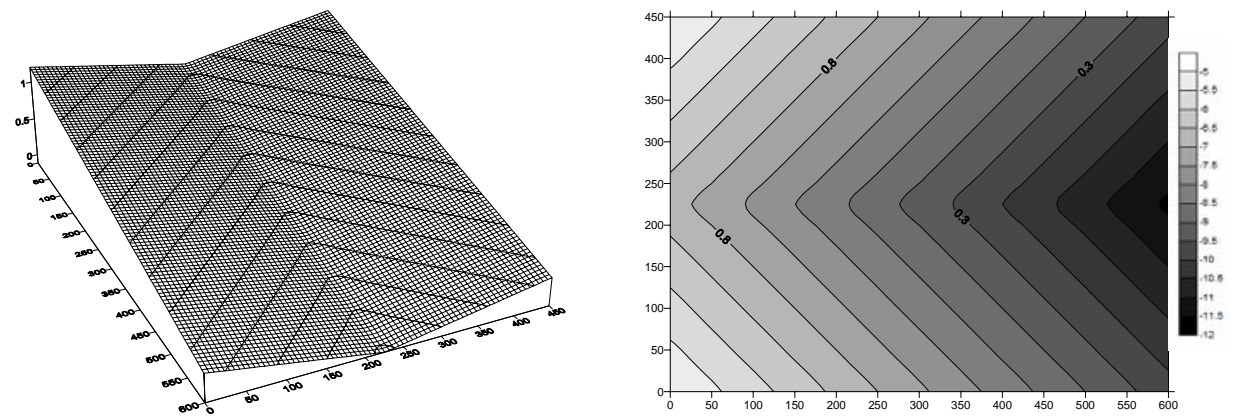

Gambar 9 Profil segitiga.

Perhitungan numerik akan dijalankan dengan data-data:
$N=0,025$
$D T=0,001$ menit
$H_{\text {yet }}=2$ inch/hour
$S_{0}=0,0016$

Hasil perhitungan numerik menunjukkan perubahan kontur permukaan air dan arah aliran yang dapat dilihat pada gambar dibawah ini.

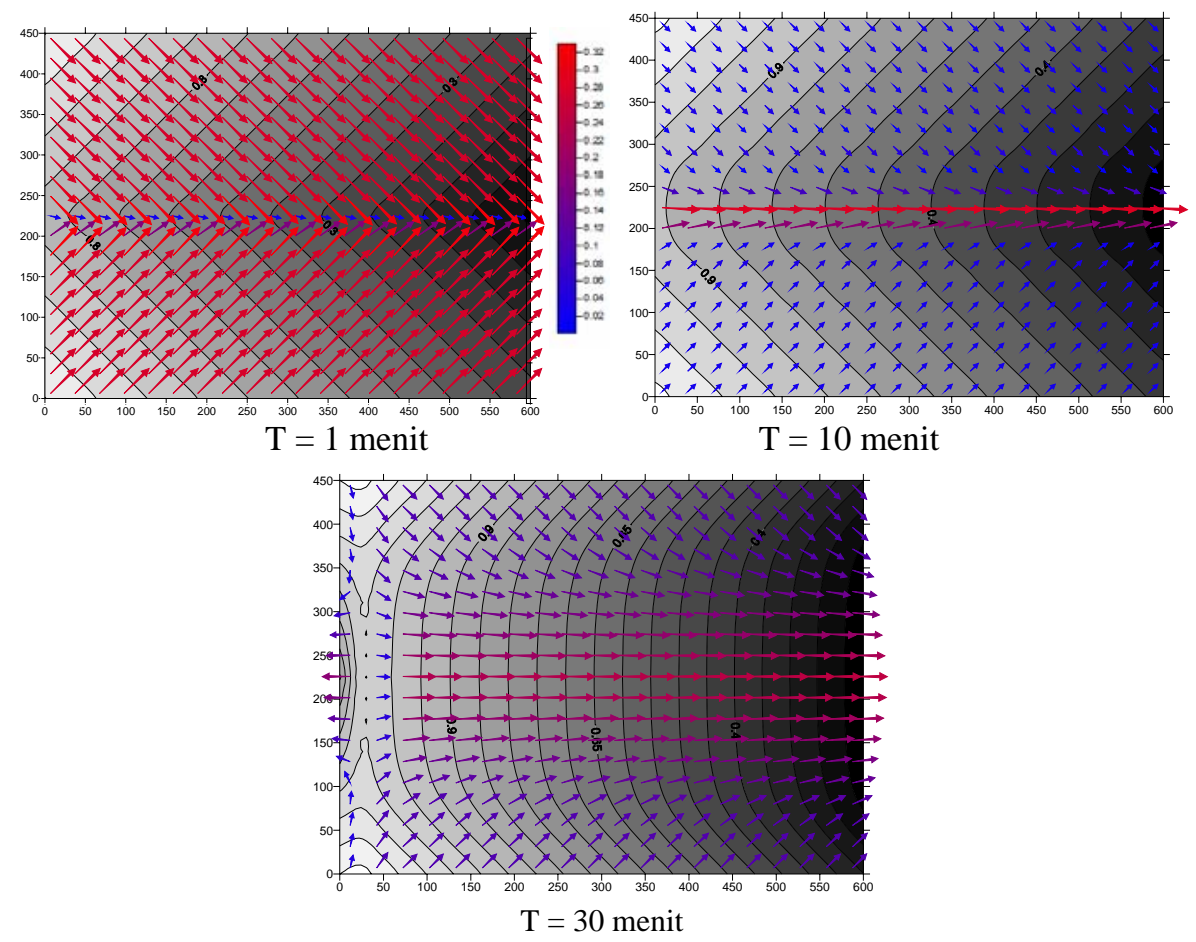

Gambar 10 Profil kecepatan dan kedalaman terhadap waktu. 
Cekungan semakin terisi air seiring dengan waktu. Perubahan pola aliran menunjukkan bahwa dengan semakin bertambahnya waktu maka air yang mengalir di tengah akan semakin bertambah karena terjadinya genangan.

\subsection{Profil Parabolik}
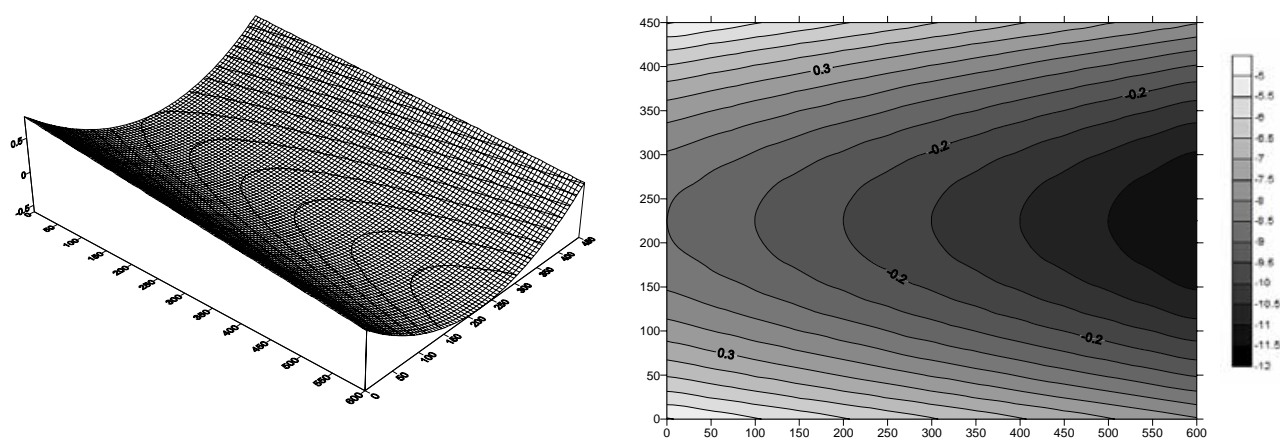

Gambar 11 Profil parabolik.

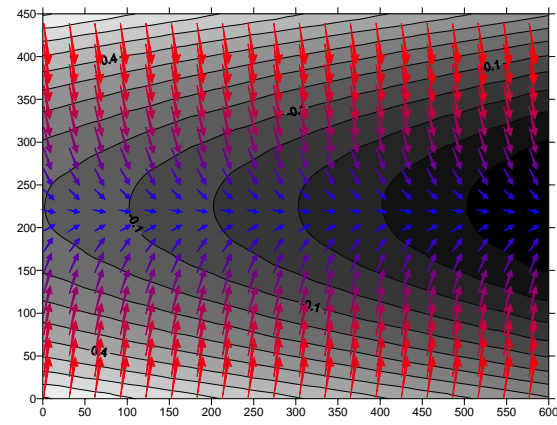

$\mathrm{T}=1$ menit

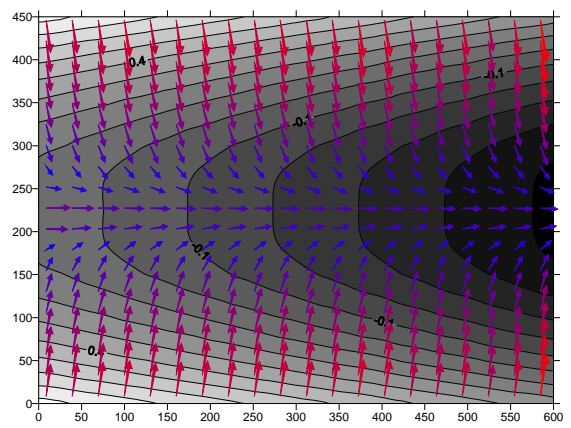

$\mathrm{T}=10$ menit

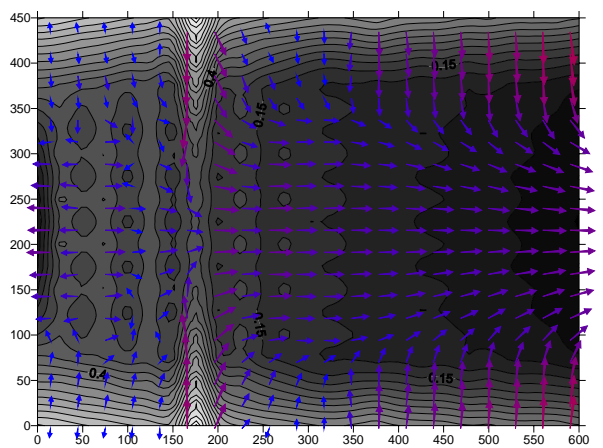

$\mathrm{T}=30$ menit

Gambar 12 Profil kecepatan dan kedalaman terhadap waktu. 
Perhitungan numerik akan dijalankan dengan data-data:
$N=0,025$
$D T=0,001$ menit
$H_{\text {yet }}=2$ inch/hour
$S_{0}=0,0016$

Hasil perhitungan numerik menunjukkan perubahan kontur permukaan air dan pola aliran yang dapat dilihat pada Gambar 12.

Cekungan semakin terisi air seiring dengan waktu. Perubahan pola aliran menunjukkan bahwa dengan semakin bertambahnya waktu maka air yang mengalir di tengah akan semakin bertambah karena terjadinya genangan.

\subsection{Profil Alam 1}
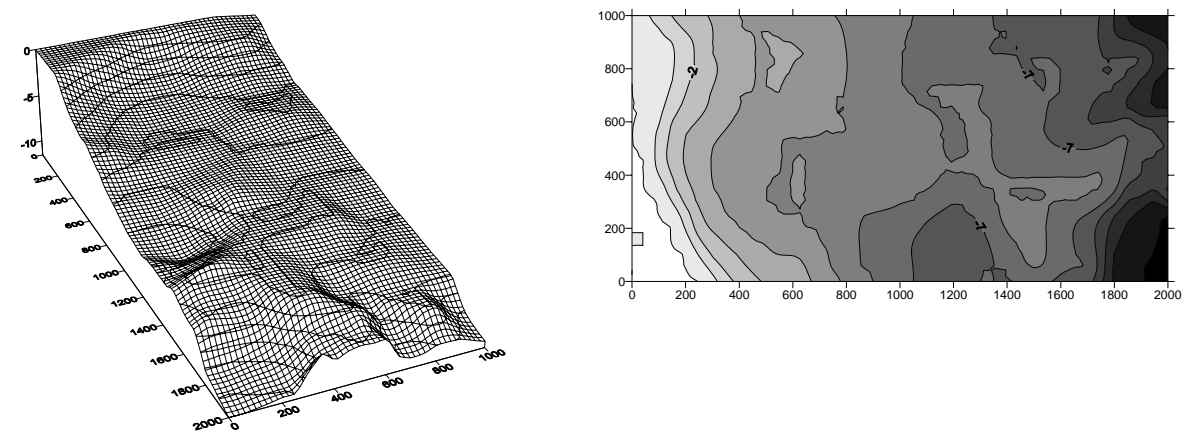

Gambar 13 Profil alam 1.

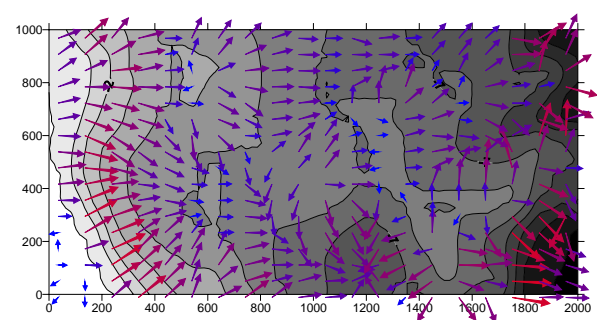

$\mathrm{T}=1$ menit

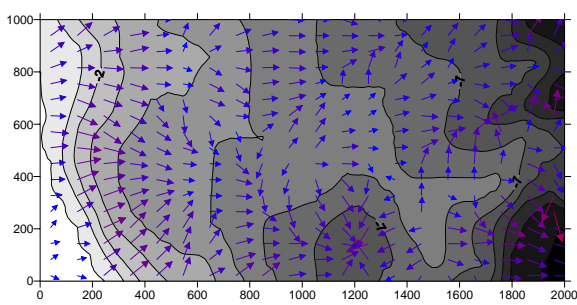

$\mathrm{T}=5$ menit

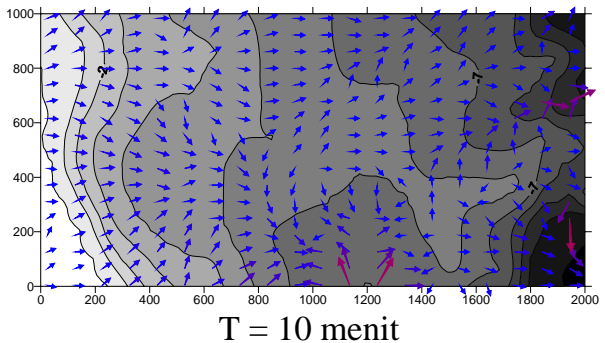

Gambar 14 Profil kecepatan dan kedalaman terhadap waktu. 
Perhitungan numerik akan dijalankan dengan data-data:

$$
\begin{aligned}
& \mathrm{N}=0,025 \\
& \text { DT }=0,001 \text { menit } \\
& \text { Hyet }=2 \text { inch/hour }
\end{aligned}
$$

Hasil perhitungan numerik menunjukkan perubahan kontur permukaan air yang dapat dilihat pada Gambar 14.

Terlihat bahwa ceekungan-cekungan pada kontur diatas semakin penuh terisi air dengan bertambahnya waktu. Perubahan pola aliran menunjukkan bahwa dengan semakin bertambahnya waktu maka pola aliran air akan semakin teratur mengalir ke daerah yang lebih rendah. Cekungan-cekungan yang terisi air menyebabkan arah aliran di beberapa daerah berubah.

\subsection{Profil Alam 2}
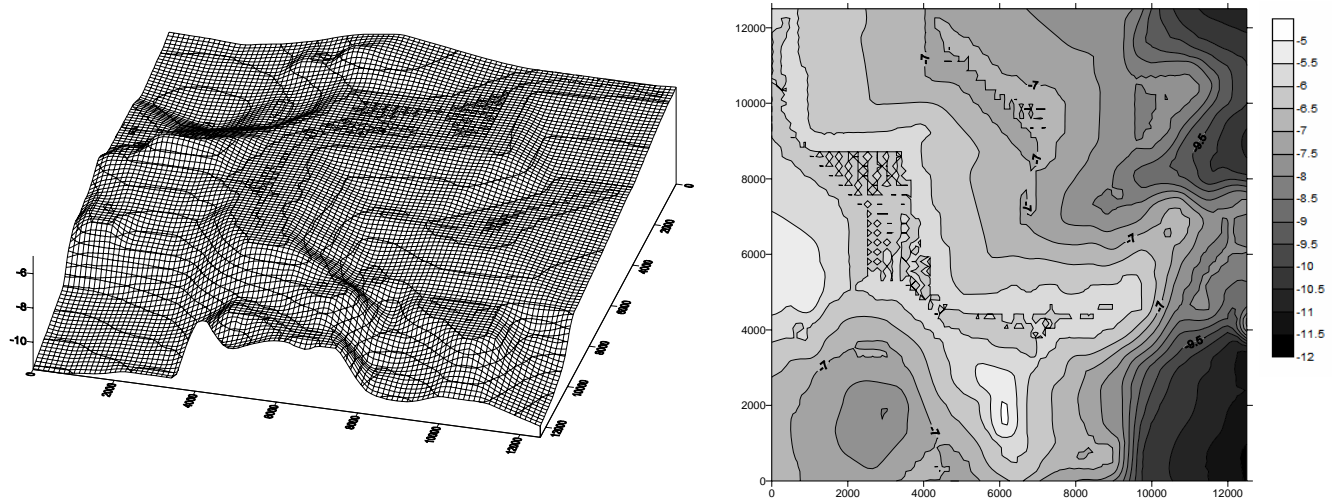

Gambar 15 Profil alam 2.

Perhitungan numerik akan dijalankan dengan data-data:
$\mathrm{N} \quad=0,025$
DT $\quad=0,001$ menit
Hyet $=2$ inch/hour

Terlihat bahwa cekungan-cekungan pada kontur diatas semakin penuh terisi air dengan bertambahnya waktu. Perubahan pola aliran menunjukkan bahwa dengan semakin bertambahnya waktu maka pola aliran air akan semakin teratur mengalir ke daerah yang lebih rendah. Cekungan-cekungan yang terisi air menyebabkan arah aliran di beberapa daerah berubah. 

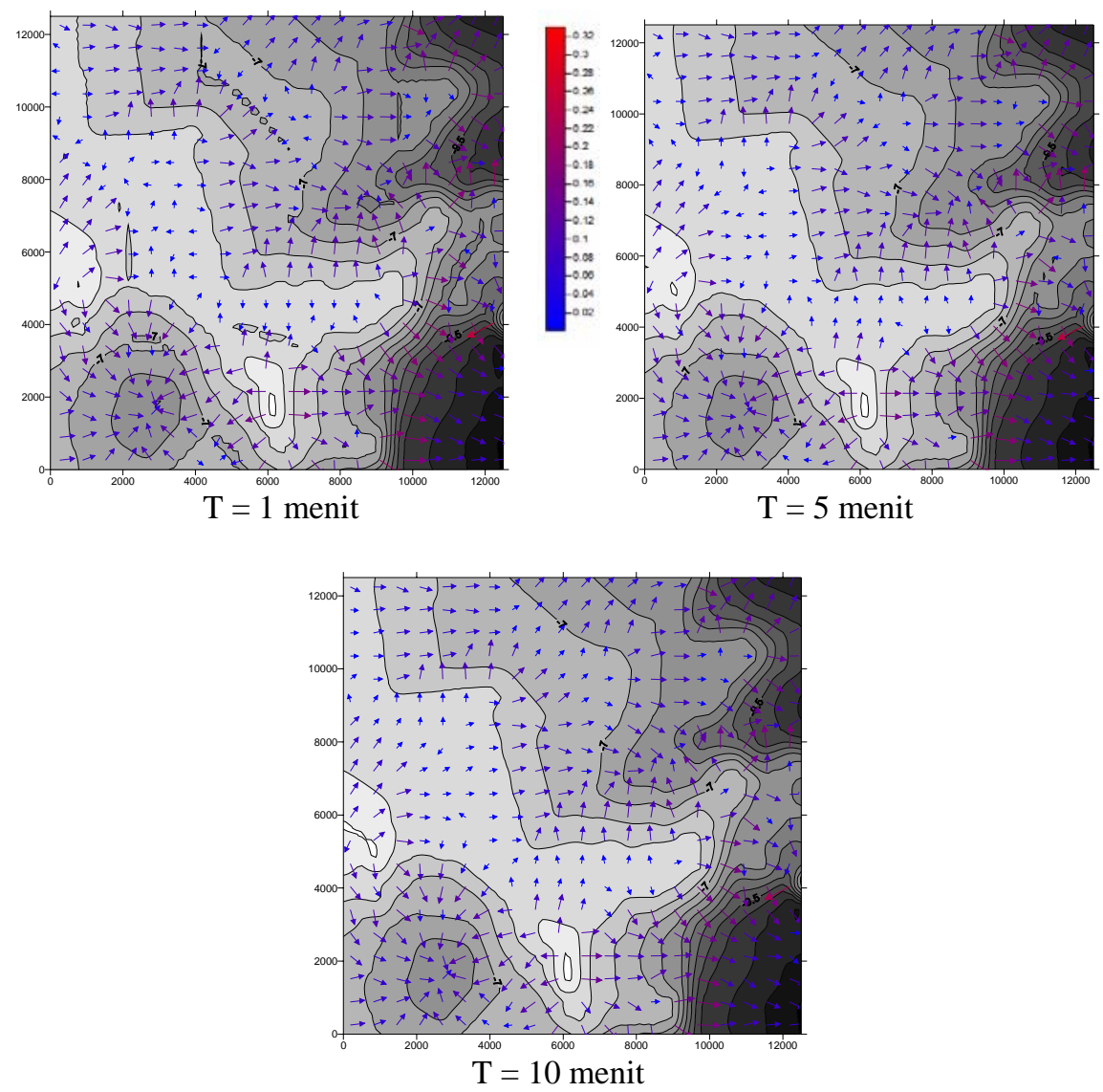

Gambar 16 Profil kecepatan dan kedalaman terhadap waktu.

\section{$5 \quad$ Kesimpulan}

Berdasarkan uraian dari penjelasan sebelumnya dapat diambil kesimpulan sebagai berikut:

1. Model numerik yang telah dikembangkan berupa metode explicit MacCormack yang dapat mensimulasikan aliran limpasan permukaan dengan baik. Hal ini terbukti melalui perbandingan yang dilakukan dengan solusi analitik. Hasil yang diperoleh melalui simulasi numerik mendekati dengan solusi analitiknya.

2. Penerapan pada kontur alam dapat mewakili kondisi sebenarnya yang terjadi. 


\section{Daftar Pustaka}

[1] Harto, Sri, Analisis Hidrologi, Penerbit PT. Gramedia Jakarta, 1993.

[2] Arsyad, Konservasi Tanah dan Air, Cetakan ke-1, Penerbit IPB, 1989.

[3] Sinukaban, Banuwa, Effect of Soil and Water Conservation Practices on Runoff, Erosion, and Nutrient Loss from Vegetable Growing Areas, Jurnal Ilmu Pertanian Indonesia, 5, 76-81, 1995.

[4] Sosrodarsono, Suyono \& Kensaku, Takeda, Hidrologi - Manual on Hydrology Untuk Pengairan, Cetakan 6, Pradnya Paramita Jakarta, 1987.

[5] Triatmodjo, Bambang, Hidraulika, Beta Offset Yogyakarta, 1993.

[6] Griffiths, D.V., Smith, I.M., Numerical Methods for Engineers, Blackwell Scientific Publications, 1985.

[7] Salim, Hang Tuah, Kusuma, M. Syahril B. \& Nazili, Limpasan dan Kapasitas Erosi pada Suatu DAS yang Masuk ke Palung Sungai, Jurnal ITB Pemodelan Hubungan Hujan, 2004.

[8] Cahyono, M., Materi Kuliah Hidraulika Lanjut, Penerbit ITB Bandung, 2001.

[9] Harto, Sri, Disertasi Rangkaian Sifat Dasar Hidrograf Satuan Sungai Sungai di Pulau Jawa untuk Perkiraan Banjir, UGM Yogyakarta, 1985.

[10] Sungono, Buku Teknik Sipil, Penerbit Nova Bandung, 1988.

[11] Sosrodarsono, Suyono \& Kensaku, Takeda, Hidrologi Untuk Pengairan, Pradnya Paramita Jakarta, 1976.

[12] Chow, Ven Te, Applied Hidrology, McGraw - Hill International Editions, 1987.

[13] Chow, Ven Te, Open Channel Hydraulics, McGraw-Hill Kogasuha, 1959.

[14] Rachmat, Y., Model Numerik Simulasi Aliran Limpasan Permukaan 2D Dengan Metoda Mac-Cormack, Tesis Magister Dept. Teknik Sipil ITB, 2003. 